\title{
QUALITY EVALUATION OF GNOCCHI PASTA PREPARED WITH ORANGE-FLESHED SWEET POTATO
}

\author{
AVALIAÇÃO DA QUALIDADE DE MASSAS DO TIPO NHOQUE ELABORADAS \\ COM BATATA-DOCE DE POLPA ALARANJADA
}

\author{
Erika Madeira Moreira da SILVA ${ }^{1}$; Amanda Ferreira ROSSINI ${ }^{2}$; \\ José Luiz Viana de CARVALHO \\ 1. Professor, PhD, Federal University of Espírito Santo - UFES, Health Sciences Center, Vitória, ES, Brazil \\ erika.alimentos@gmail.com; 2. Nutritionist, Federal University of Espírito Santo - UFES, Health Sciences Center, Maruípe, Vitória, ES, \\ Brazil; 3. Researcher, Embrapa Food Technology, Rio de Janeiro, RJ, Brazil.
}

\begin{abstract}
Considering the increase of pasta market and the importance of orange-fleshed sweet potato (OFSP) nutritional value and economic aspects, this study aimed to evaluate the effect of the addiction of OFSP and potato starch on the physical characteristics of gnocchi pasta during cooking, as well as to determine the chemical and sensory characteristics of the best samples, analyzing them during storage. A central composite rotational $2^{\text {nd }}$ order experimental design was employed to investigate the effects of adding $63.65 \%$ to $75.81 \%$ OFSP and $35.86 \%$ to $64.14 \%$ potato starch during the cooking of the pasta. The best treatments were analyzed for acceptability, chemical composition and behavior during storage. The addition of OFSP affected only the cooking time by causing an increase in this value. Moreover, it positively contributed to the acceptability of the product, especially the color, as well as to the increase of the fiber and ash contents. It is recommended to consume immediately after preparation. If storage is necessary, the refrigeration at $4{ }^{\circ} \mathrm{C}$ is suggested, provided that packaging requirements are met, preferably vacuum packaging.
\end{abstract}

KEYWORDS: Ipomoea batatas. Agricultural cultivation. Quality control. Sensory. Nutrition.

\section{INTRODUCTION}

Orange-fleshed sweet potato (OFSP), Beauregard cultivar, is considered to be promising in biofortification programs, especially in Brazil. This cultivar has elongated, uniform, elliptical-type roots, with red-purple skin and smooth surface. The intense orange flesh is due to the high content of beta carotene, an average 115 $\mathrm{mg}$ per kilogram of this nutrient per fresh root. This cultivar can be consumed in the same way as any other sweet potato cultivars (MELO, 2011). In addition, this variety has a low glycemic index when raw $(32 \pm 3.0)$ and a moderate index $(66 \pm$ 5.7) when cooked in a microwave (ALLEN et al., 2012), playing an important role in the age of obesity and diabetes growth.

Researchers have observed acceptability rates (above $70 \%$ ) for this cultivar, as well as total carotenoids retention levels around 90\% in the preparation of bakery products and dry pasta (LIMROONGREUNGRAT; HUANG, 2007; RANGEL et al., 2011; SICILIANO et al., 2009).

According to ABIMA - Brazilian Association of Pasta Industries (2011), Brazil occupies the third place in the global pasta market, with progressive increases in the production of such products from 2008 to 2012, with an average consumption of $6,2 \mathrm{~kg} /$ person/year.
However, very few studies have been conducted with fresh pasta, especially gnocchi type pasta. From 2005 to this date, only two studies were published (ALESSANDRINI et al., 2010; ZEPPA et al., 2005), but none of them studied the behavior of sweet-potato in the development of such products.

Besides tasty, gnocchi-type pasta are relatively easy to prepare and consume. However, commercially available pastas have a rather whitish color which in some cases adversely affects consumer selection.

Thus, this study aimed to evaluate the effect of the addiction of OFSP and potato starch on the physical characteristics of gnocchi-type pasta during cooking, as well as to determine the chemical and sensory characteristics of the best samples, analyzing them during storage.

\section{MATERIAL AND METHODS}

\section{Pasta ingredients and preparation \\ Embrapa Horticulture (Brasília-DF, Brazil) provided Beauregard variety orange-fleshed sweet potato roots were used as main raw material. The remaining ingredients employed in each formulation, such as margarine $(15 \mathrm{~g})$, salt $(5 \mathrm{~g})$, egg $(46 \mathrm{~g})$, wheat flour and potato starch (according to the experimental design) were acquired in Vitória- ES (Brazil) marketplace. Experiments were conducted at Federal University of Espírito Santo, at}


Health Sciences Center's Dietary Technique Laboratory (CCS-UFES), where preliminary tests were conducted aiming to get a standard formulation. Thus, potatoes were washed and immersed in a $250 \mathrm{mg} / \mathrm{l}$ sodium hypochlorite solution for $15 \mathrm{~min}$ and frozen-stored $\left(-25^{\circ} \mathrm{C}\right)$ in a freezer (Brastemp flex) until preparation time. For pasta preparation, the potatoes were previously cooked in a microwave oven (Consul) using $90 \%$ power for 10 minutes for each root. Thereafter the potatoes were peeled, macerated and mixed with the other ingredients, molded in a manual gnocchi maker and then cooked for subsequent analysis.

\section{Experimental design}

The central composite rotational experimental design (BOX; DRAPER, 1987) was used in order to study the combined effect of orange-fleshed sweet potato variables - OFSP (\%) and potato starch (\%) in substitution of wheat flour, on the physical characteristics of gnocchi pasta. Variables were set up at levels encoded with four replicates at the central point, four levels at the axial point and four factorials, totaling twelve experiments (Table 1). The focus of experiment was proposed based on preliminary tests, as well as on the information available in the literature. The remaining ingredients were used in the same quantity in all tests.

\section{Pasta cooking test}

The cooking test was conducted according to the modified Ciacco and Chang (1986) and Leitão et al. (1990) technique, characterized as cooking time (CT min), weight increase (WI\%), volume increase (VI\% ) and cooking loss (CL\%). Analyzes were performed using $100 \mathrm{~g}$ pasta, in duplicate. Optimal cooking time (OCT) was determined by cooking 100g sample in $1000 \mathrm{ml}$ of boiling water until the sample reached the surface of the cooking water. It is important to point out that the temperature levels were constantly monitored by a thermometer. The cooking temperature ranged from 95 to $100^{\circ} \mathrm{C}$. Pasta weight gain was determined by weighing $100 \mathrm{~g}$ pasta before and after cooking, considering the optimal cooking time for each sample. Weight increase is the ratio between the weight of the cooked pasta and the weight of the raw pasta, expressed in percentage $(\%)$. Volume increase was determined by the displacement of the water in a beaker, in the samples before and after cooking. This parameter (VI) was calculated by considering the difference between the volume of water displaced into the raw pasta (v1) and the volume of water displaced into the cooked pasta (v2), with the result expressed in a percentage, according to equation 1 .

$$
A V(\%)=\frac{V 2-V 1 * 100}{V 1}(E q .1)
$$

The amount of solids lost to the cooking water (CL) was determined by evaporating $50 \mathrm{ml}$ of post-cooking water in an oven with air circulation (Tecnal), at $105^{\circ} \mathrm{C}$ to constant weight. For CL equation 2 was employed:

$S S(\%)=\frac{A * 40}{100 * U} * 100(E q .2)$

where:

$\mathrm{A}=$ plate weight difference before and after the oven

$\mathrm{U}=$ sample moisture content

$40=$ dilution factor

Thus, after pasta physical characterization, selection criteria were adopted, according to results achieved, to be submitted to sensory analysis.

\section{Sensory analysis}

The pasta selected whose behavior during the cooking test was considered ideal, were submitted to the acceptability test by a 9-point hedonic scale $(9=$ like extremely, $5=$ neither like nor dislike, and $1=$ dislike extremely) according to the methodology proposed by Dutkoski (2013). The test included 54 untrained panelists who received samples of the gnocchi pasta served with tomato sauce, monadically among randomly selected with a 3 -digit code, accompanied with mineral water and the evaluation form. The test was carried out in individual cabins under white lighting. The panelists were asked to voluntarily sign the Informed Consent Form (ICF). This study was submitted to and approved by the Research Ethics Committee of Federal University of Espírito Santo, Health Sciences Center (number 302.657).

\section{Pasta chemical characterization}

Treatments selected by the sensory analysis were analyzed for their chemical composition, in duplicate, according to Association of Official Analytical Chemists (AOAC, 2005). Moisture content was determined (within an oven with air circulation at $105^{\circ} \mathrm{C}$ ), ash (by incineration in a muffle oven at $550^{\circ} \mathrm{C}$ ), protein (nitrogen, Kjeldahl method - conversion factor 6.25), lipids (Soxhlet method) and dietary fiber (by enzymatic-gravimetric method). Total carbohydrates were calculated by difference: $100-$ (moisture + protein + ash + lipids). Energy value was determined in kcal, according to the following formula $=\left(\begin{array}{llll}\text { protein } \% & \mathrm{x} & 4\end{array}\right)+$ (carbohydrate \% x 4) + (lipids \% x 9). 


\section{Pasta storage time evaluation}

Pastas selected by the sensory analysis were submitted to the cooking test on the first day at preparation, on the $7^{\text {th }}$ day of storage under refrigeration at $4^{\circ} \mathrm{C}$, and after 30 days in a freezer at $-25^{\circ} \mathrm{C}$. The pasta was stored in vacuum-sealed, medium density polyethylene bags.

\section{Data Analysis}

The significance of the model (linear and quadratic) was tested by analysis of variance ( $F$ test). Pareto charts were used to represent the model applied, as well as the effect of the dependent variables (OFSP and potato starch) on the cooking test variables. A potential relationship between such variables was also checked by employing the Pearson correlation. The results of the sensory analysis, chemical composition and storage test were subjected to the analysis of variance (ANOVA oneway) followed by Tukey test. All analyzes were performed assuming a 5\% probability. The results of this study were analyzed using Statistica 10.0 software.

\section{RESULTS AND DISCUSSION}

\section{Pasta cooking test}

The results of the physical characterization of the cooking test are shown in Table 1. According to the results of the tests conducted, it was observed that the cooking time (CT) increased in proportion to the OFSP content (up to $75.81 \%$ ) (Figure 1A). The CT varies between 1.10 and 2.45 minutes, less than the time range shown by Paucar-Menacho et al. (2008) for enriched fresh pasta. Other variables, such as weight increase (WI), volume increase (VI) and cooking loss (CL) were not affected by different proportions of OFSP and potato starch $(\mathrm{P}>0.05)$ (Figures 1B, 1C, 1D). These results allowed us to assume that the insertion of OFSP up to $75.81 \%$ in the fresh pasta does not significantly influence the final quality of the product, especially solids loss during cooking.
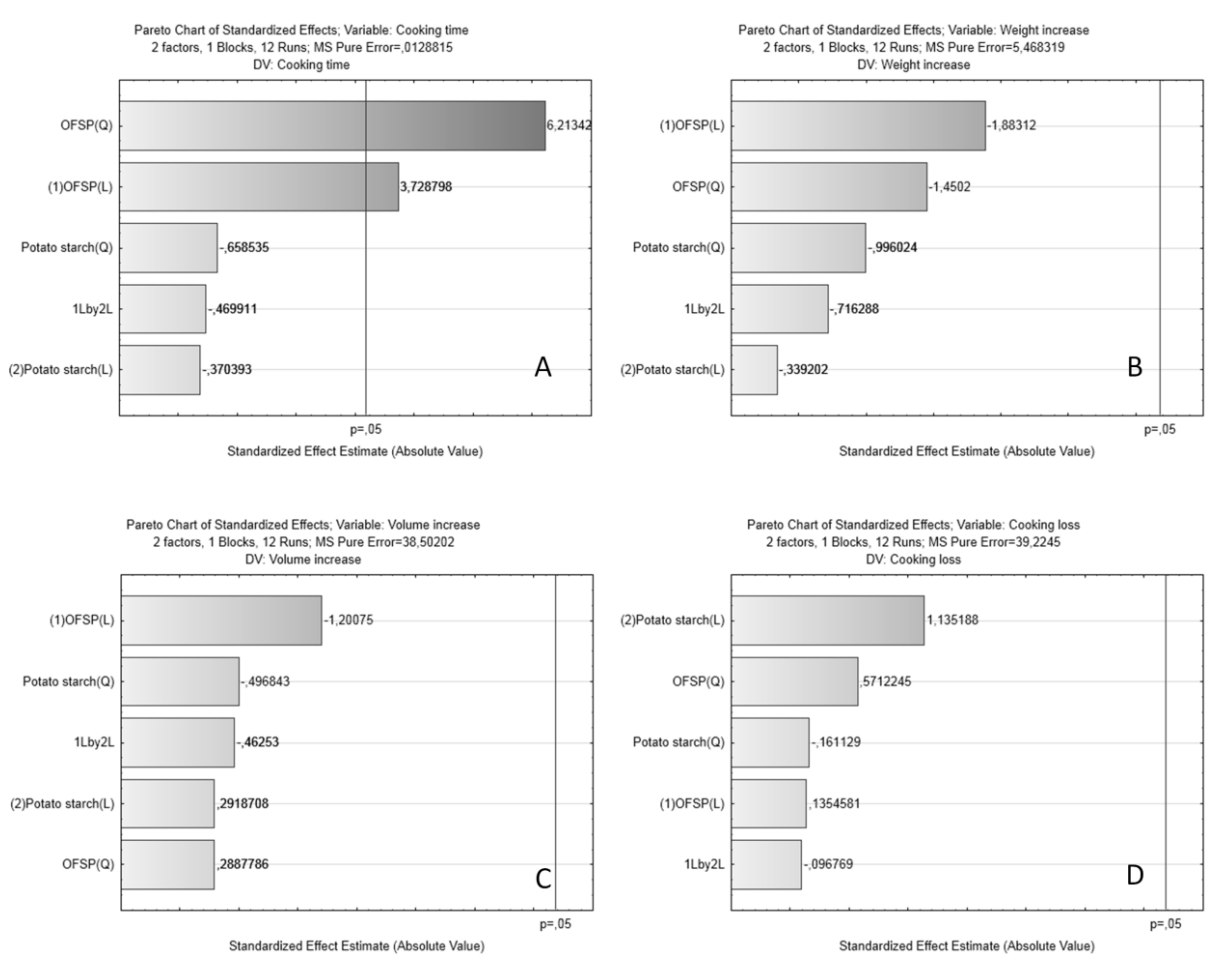

Figure 1. Pareto Charts showing the impact of adding orange-fleshed sweet potato (OFSP) and potato starch on the pasta cooking physical characteristics regarding: (A) cooking time; (B) weight increase; (C) volume increase and (D) cooking loss.

No evidence of a significant WI was observed in gnocchi pasta, which ranged between 6.27 and $13.87 \%$. The same has had already been observed by Chang and Flores (2004), where the fresh pasta prepared with semolina showed little variation in weight values. This small difference between samples WI can be explained by the fact that fresh pasta has higher pre-cooking moisture content when compared to dry pasta, which usually double their initial weight. It also became evident 
that, unlike Limroongreungrat and Huang (2007) findings, the addition of OFSP along with the addition of potato starch (concentrations determined in the experimental design) did not significantly impacted solids loss during the cooking. For Hummel (1966), dry noodles showing up to $6 \%$ solids loss is regarded as good; up to $8 \%$, regular; and above $10 \%$, is regarded as poor. However, there is no solids loss value considered as ideal for fresh pasta; but for any pasta to be considered as good quality it is important that such solids loss is minimal (ALESSANDRINI et al., 2010). In the case of fresh pasta, components not strongly linked to the molecular structure may be present due to the intrinsic characteristic of the raw materials and these have a potential to suffer leaching losses. Furthermore, Beauregard OFSP may also presents a high amount of soluble starch (data not analyzed), seeing that when potato is immersed in water there is turbidity in the water, which is typical of solubilized starch.

Table 1. Results ${ }^{\dagger}$ of gnocchi pasta physical characteristics with orange-fleshed sweet potato (OFSP) and potato starch.

\begin{tabular}{|c|c|c|c|c|c|c|c|c|}
\hline \multirow[b]{2}{*}{ Treatments } & \multicolumn{2}{|c|}{$\begin{array}{c}\text { Encoded } \\
\text { variables } \\
\text { levels }\end{array}$} & \multicolumn{2}{|c|}{ Actual variables levels } & \multirow[b]{2}{*}{$\begin{array}{l}\mathrm{CT} \\
(\mathrm{min})\end{array}$} & \multirow[b]{2}{*}{$\begin{array}{l}\text { WI } \\
(\%)\end{array}$} & \multirow[b]{2}{*}{$\begin{array}{r}\text { VI } \\
(\%)\end{array}$} & \multirow[b]{2}{*}{$\begin{array}{r}\mathrm{CL} \\
(\%) \\
\end{array}$} \\
\hline & $\mathrm{X} 1$ & $\mathrm{X} 2$ & OFSP $(\%)$ & $\begin{array}{c}\text { Potato Starch } \\
(\%)\end{array}$ & & & & \\
\hline 1 & -1 & 1 & 65.3 & 60 & $1.40(0.05)$ & $10.35(1.41)$ & $12.50(0.00)$ & $26.23(0.43)$ \\
\hline 2 & -1 & -1 & 65.3 & 40 & $1.26(0.02)$ & $8.55(0.69)$ & $20.00(0.00)$ & $12.12(0.00)$ \\
\hline 3 & 1 & 1 & 73.3 & 60 & $1.23(0.07)$ & $7.20(1.21)$ & $11.76(0.00)$ & $25.80(0.00)$ \\
\hline 4 & 1 & -1 & 73.3 & 40 & $1.20(0.01)$ & $8.75(2.87)$ & $25.00(0.00)$ & $12.90(0.00)$ \\
\hline 5 & -1.41 & 0 & 63.65 & 50 & $1.34(0.05)$ & $13.87(0.60)$ & $22.20(0.00)$ & $24.24(0.00)$ \\
\hline 6 & 1.41 & 0 & 75.81 & 50 & $2.47(0.01)$ & $6.27(0.64)$ & $5.55(0.00)$ & $26.23(0.43)$ \\
\hline 7 & 0 & -1.41 & 69.3 & 35.86 & $1.42(0.09)$ & $12.02(1.35)$ & $0.00(0.00)$ & $24.24(0.00)$ \\
\hline 8 & 0 & 1.41 & 69.3 & 64.14 & $1.21(0.02)$ & $10.25(3.82)$ & $18.29(0.00)$ & $19.35(6.45)$ \\
\hline 9 & 0 & 0 & 69.3 & 50 & $1.21(0.04)$ & $13.80(1.86)$ & $11.11(0.00)$ & $17.64(5.88)$ \\
\hline 10 & 0 & 0 & 69.3 & 50 & $1.35(0.05)$ & $8.65(1.27)$ & $11.11(0.00)$ & $25.00(0.00)$ \\
\hline 11 & 0 & 0 & 69.3 & 50 & $1.32(0.03)$ & $13.38(3.05)$ & $23.52(0.00)$ & $16.06(0.00)$ \\
\hline 12 & 0 & 0 & 69.3 & 50 & $1.10(0.02)$ & $11.80(0.89)$ & $11.11(0.00)$ & $13.33(0.00)$ \\
\hline
\end{tabular}

X1: Orange-fleshed sweet potato (OFSP); X2: Potato starch; CT: Cooking time; WI: weight increase; VI: volume increase; CL: cooking loss. $†$ Mean (standard deviation)

It was also observed, according to Table 2, that no correlations between variables $(\mathrm{P}>0.05)$ were detected, suggesting that they have independent behaviors during the preparation. It is relevant to highlight that the $\mathrm{CT}$ had no relation with the other variables, including the CL. This finding is not in accordance with Sobota and Zarzycki (2013) where increased cooking time favored the loss of solids during the cooking of fresh pasta.

Table 2. Pearson Correlation applied to cooking test parameters of gnocchi pasta.

\begin{tabular}{lllll}
\hline \multicolumn{5}{c}{ Weight increase (\%) Cooking time (min) Volume increase (\%) Cooking loss (\%) } \\
\hline Weight increase (\%) & $1.000000^{*}$ & & & \\
Cooking time (min) & $-0.460474^{*}$ & $1.000000^{*}$ & & \\
Volume increase (\%) & $0.174764^{*}$ & $-0.414962^{*}$ & $1.000000^{*}$ & \\
Cooking loss & $-0.018357^{*}$ & $0.450603^{*}$ & $-0.328430^{*}$ & $1.000000^{*}$ \\
$\quad(\%)$ & & &
\end{tabular}

\section{Sensory analysis}

Considering that the insertion of different OFSP concentrations only influenced the CT, treatments with axial levels of OFSP were adopted as selection criteria, referring to T5 (63.65\% OFSP) and T6 (75.81\% OFSP) samples. Although an increased OFSP level will increase the pasta CT, it cannot be considered a limiting factor since gnocchi 
pasta is commercially sold fresh and its cooking time is usually short if compared to dry pasta. Besides, the sample having the smallest potato starch (T7 with 35.86\%) content was also selected because, although potato starch as an ingredient will help in the preparation of the pasta, any excess will cause the pasta to become tough and sensory undesirable (visually analyzed). Considering the results of the analysis of variance for sensory attributes, as well as for purchase intention, no difference was observed among the items evaluated in the tasted samples (Table 3).

Table 3. Sensory evaluation* of gnocchi pasta made with different proportions of orange-fleshed sweet potato (OFSP) and potato starch.

\begin{tabular}{ccccccc}
\hline Treatments & Appearance & Taste & Color & Aroma & Texture & $\begin{array}{c}\text { Purchase } \\
\text { intention }\end{array}$ \\
\hline T5 & $7.77^{\mathrm{a}}$ & $7.47^{\mathrm{a}}$ & $7.90^{\mathrm{a}}$ & $7.89^{\mathrm{a}}$ & $7.57^{\mathrm{a}}$ & $6.77^{\mathrm{a}}$ \\
T6 & $7.85^{\mathrm{a}}$ & $7.36^{\mathrm{a}}$ & $8.02^{\mathrm{a}}$ & $7.77^{\mathrm{a}}$ & $7.70^{\mathrm{a}}$ & $6.98^{\mathrm{a}}$ \\
T7 & $8.00^{\mathrm{a}}$ & $7.57^{\mathrm{a}}$ & $8.09^{\mathrm{a}}$ & $8.06^{\mathrm{a}}$ & $7.92^{\mathrm{a}}$ & $7.24^{\mathrm{a}}$ \\
\hline
\end{tabular}

* Means $(\mathrm{n}=53)$. Means with the same letters in the same column are not significant, considering a confidence interval of $95 \%$ (Tukey test). Treatments: T5 (63.65 \% OFSP and 50\% potato starch); T6 (75\% OFSP and 50\% potato starch) and T7 (69.3\% OFSP and 35.85\% potato starch).

From Table 3 it can be observed that the averages allocated to each sensory attribute were good, as indicated in the hedonic scale between "like moderately" and "liked very much". Regarding the purchase intention, it is to be highlighted that the panelists, in most cases, were not undecided about purchasing the product, but they rather assigned grades near certainty.

Color is the first sensory attribute consumers use to judge the acceptability of a food (CARINI et al., 2009). Color will influence consumers because it can be perceived as a freshness indicator. Very likely, these results are related to the addition of OFSP, giving the products a more attractive color. Rangel et al. (2011), using OFSP as main raw material to prepare cakes, observed that the final products achieved high averages in general acceptability, also similar to the control product (without OFSP). Researchers conducting studies with gnocchi observed acceptability levels above $70 \%$ for this type of product (TAVARES; GUTIERREZ, 2008; CUELHAR, 2004).

\section{Chemical characterization}

Table 4 shows the chemical composition of gnocchi samples with different percentage of OFSP and potato starch. A control sample was used for this analysis (prepared with conventional grayfleshed sweet potato and potato starch in the concentrations used in the central point of the experimental design - $69.3 \%$ and $50 \%$, respectively). It is evident that the OFSP-added samples have higher moisture contents, as well ash and fiber, especially the higher the root content in the formulation. No significant differences were found between protein and lipid contents for all treatments. This is explained by the fact that OFSP and potato starch are essentially starchy raw materials.

Table 4. Chemical composition* of gnocchi pasta with different percentages of OFSP and potato starch.

\begin{tabular}{lcccc}
\hline \multicolumn{5}{c}{ Treatments } \\
\hline $\begin{array}{l}\text { Composition } \\
\text { (g/100g dry } \\
\text { basis) }\end{array}$ & TC & T5 & T6 & T7 \\
\hline Moisture & $59.17(0.52)^{\mathrm{c}}$ & $62.59(0.09)^{\mathrm{b}}$ & $65.67(0.00)^{\mathrm{a}}$ & $61.56(0.06)^{\mathrm{b}}$ \\
Ash & $2.23(0.02)^{\mathrm{c}}$ & $2.67(0.01)^{\mathrm{ab}}$ & $2.74(0.00)^{\mathrm{a}}$ & $2.51(0.06)^{\mathrm{b}}$ \\
Proteins & $0.60(0.20)^{\mathrm{a}}$ & $0.44(0.03)^{\mathrm{a}}$ & $0.32(0.16)^{\mathrm{a}}$ & $0.48(0.24)^{\mathrm{a}}$ \\
Lipids & $9.27(0.49)^{\mathrm{a}}$ & $7.38(1.11)^{\mathrm{a}}$ & $6.59(0.20)^{\mathrm{a}}$ & $7.51(0.23)^{\mathrm{a}}$ \\
Fiber & $7.18(0.56)^{\mathrm{b}}$ & $7.35(0.13)^{\mathrm{b}}$ & $8.76(0.01)^{\mathrm{a}}$ & $8.14(0.16)^{\mathrm{ab}}$ \\
Carbohydrates & $28.71(0.19)^{\mathrm{a}}$ & $26.90(1.15)^{\mathrm{ab}}$ & $24.67(0.03)^{\mathrm{b}}$ & $27.93(0.01)^{\mathrm{ab}}$ \\
Kcal $(100 \mathrm{~g})$ & $200.73(4.47)^{\mathrm{a}}$ & $175.86(5.27)^{\mathrm{bc}}$ & $159.27(1.00)^{\mathrm{c}}$ & $181.27(1.15)^{\mathrm{b}}$ \\
\hline
\end{tabular}

* Means (standard deviation). Means followed by the same letters in the same line indicate no significance, considering a confidence interval of $95 \%$ (Tukey test). Treatments: TC (control) $-69.3 \%$ conventional sweet potato and 50\% starch; T5 - 63.65\% OFSP and 50\% potato starch; T6- 75.81\% OFSP and 50\% potato starch; T7 - 69.3\% OFSP and 35.86\% potato starch. 


\section{Pasta storage time evaluation}

The results of the gnocchi pasta cooking test during the storage are shown in Table 5. The 30-day freezing conditions contributed to an increase in T6 sample CT as well as in T5 and T6 samples WI. On the other hand, refrigeration conditions helped both to reduce CT and VI in sample T5 (63\% OFSP and $50 \%$ starch). Increasing OFSP content (T6 and T7) favored pasta volume reduction after the freezing period. The starchy structure of the formulations will show different behaviors when subjected to refrigeration or freezing conditions. At approximately $4^{\circ} \mathrm{C}$ enzymatic processes are reduced, but not terminated. In addition, water absorption during storage under refrigeration is still possible. Thus, starch may undergo changes. OFSP roots, even when previously boiled, will contain other components that may influence the formation of hydrogen bonds during the starch gelatinization process such as, for example, fibers and other simple sugars, differing from potato starch. For Alessandrini et al. (2010), when vacuum packed and stored under refrigeration $\left(4^{\circ} \mathrm{C}\right)$ gnocchi pasta will achieve shelf-life of up to 2 months. Under freezing at $-25^{\circ} \mathrm{C}$, both the enzymatic processes and the changes in starchy structure are paused. Besides, depending on the type of freezing applied, the pasta may show small or large ice crystals that have a potential to interfere with the quality of the final product. For this reason, submit the products into a rapid freezing equipment is extremely important.

Table 5. Cooking test results* during storage.

\begin{tabular}{ccccc}
\hline & Treatments & Day 01 & Day 07 & Frozen - day 30 \\
\hline Cooking time & T5 & $1.31(0.04)^{\mathrm{a}}$ & $1.18(0.01)^{\mathrm{b}}$ & $1.30(0.02)^{\mathrm{a}}$ \\
(min) & T6 & $1.23(0.03)^{\mathrm{b}}$ & $1.25(0.04)^{\mathrm{b}}$ & $1.50(0.04)^{\mathrm{a}}$ \\
& T7 & $1.28(0.02)^{\mathrm{a}}$ & $1.25(0.05)^{\mathrm{a}}$ & $1.23(0.02)^{\mathrm{a}}$ \\
& & & & \\
Weight increase & T5 & $13.86(0.05)^{\mathrm{b}}$ & $13.60(0.09)^{\mathrm{b}}$ & $19.34(0.07)^{\mathrm{a}}$ \\
$(\%)$ & T6 & $11.67(0.04)^{\mathrm{b}}$ & $12.25(0.08)^{\mathrm{b}}$ & $14.52(1.30)^{\mathrm{a}}$ \\
& T7 & $13.48(0.04)^{\mathrm{b}}$ & $14.70(0.11)^{\mathrm{a}}$ & $14.51(0.77)^{\mathrm{ab}}$ \\
& & & & \\
Volume increase (\%) & T5 & $22.23(0.02)^{\mathrm{c}}$ & $37.46(0.05)^{\mathrm{a}}$ & $31.24(0.00)^{\mathrm{b}}$ \\
& T6 & $16.67(0.01)^{\mathrm{a}}$ & $16.63(0.01)^{\mathrm{a}}$ & $11.12(0.01)^{\mathrm{b}}$ \\
& T7 & $37.53(0.05)^{\mathrm{a}}$ & $31.25(0.01)^{\mathrm{b}}$ & $31.24(0.00)^{\mathrm{b}}$ \\
Cooking loss & & & & \\
$(\%)$ & T5 & $24.12(0.02)^{\mathrm{a}}$ & $21.19(0.05)^{\mathrm{a}}$ & $26.72(0.00)^{\mathrm{a}}$ \\
& T6 & $26.11(0.01)^{\mathrm{ab}}$ & $46.30(0.01)^{\mathrm{a}}$ & $17.27(0.01)^{\mathrm{b}}$ \\
& T7 & $24.12(0.05)^{\mathrm{a}}$ & $20.40(0.01)^{\mathrm{a}}$ & $15.60(0.00)^{\mathrm{a}}$ \\
\hline
\end{tabular}

* Means (standard deviation). Means followed by the same letters in the same line indicate no significance, considering a confidence interval of 95\% (Tukey test). T5 - 63.65\% OFSP and 50\% potato starch; T6- 75.81\% OFSP and 50\% potato starch; T7 - 69.3\% OFSP and $35.86 \%$ potato starch.

According to this formulations/methodology, is recommended to consume gnocchi pasta immediately after preparation. If storage is required, the refrigeration at $4^{\circ} \mathrm{C}$ is suggested, provided that packaging requirements are met, preferably vacuum packaging. It is believed that this will allow storing these products for longer than seven days. In addition, other tests such as microbiological evaluation are required to estimate with greater security the shelf life of these products.

\section{CONCLUSIONS}

The addition of orange-fleshed sweet potato concentrations between $63.65 \%$ and $75.81 \%$ in substitution of wheat flour to gnocchi pasta only affected the cooking time, causing an increase in this value. However, this was not regarded as a limiting factor seeing that fresh pasta cooking time is usually lower when compared to dry pasta.

The addition of $35.86 \%$ to $64.14 \%$ potato starch, associated or not to the OFSP addition, did not significantly impact the quality characteristics of the pasta during cooking. However, formulations containing higher levels of potato starch resulted in pasta that became too hardened after cooking (visually analyzed).

The insertion of OFSP positively contributed to sensory aspects, especially the color. In addition, it contributed to increase the contents of ash and fibers. 


\section{ACKNOWLEDGEMENTS}

The Associate Dean of Research and PostGraduate Studies of Federal University of Espírito Santo (PRPPG-UFES) and to the "Fundação de
Amparo à Pesquisa do Espírito Santo - FAPES" to the initiation scientific scholarship. Embrapa Horticulture for the donation of sweet potatoes and HarvestPlus and BioFORT biofortification programs, for the technical and financial support.

RESUMO: Frente ao crescente mercado de massas alimentícias e da importância da batata doce de polpa alaranjada (BDPA) por seu valor nutritivo e aspectos econômicos, este estudo teve como objetivo avaliar o efeito da adição de BDPA e fécula de batata nas características físicas de massas do tipo nhoque durante o cozimento, bem como determinar as características químicas e sensoriais das melhores amostras caracterizando-as durante seu armazenamento. Utilizou-se um delineamento central composto rotacional de $2^{\mathrm{a}}$ ordem para investigar os efeitos da adição de $63,65 \%$ a $75,81 \%$ de BDPA e de $35,86 \%$ a $64,14 \%$ de fécula de batata durante a cocção das massas. Os melhores tratamentos foram analisados quanto a aceitabilidade, composição química e comportamento durante o armazenamento. A adição de BDPA nas massas de nhoque influenciou apenas no tempo de cozimento ocasionando aumento deste valor. Além disso, contribuiu positivamente para a aceitabilidade do produto, em especial à cor, bem como para o aumento dos teores de resíduo mineral e fibras. Recomenda-se que o consumo seja imediato, após o preparo. Sendo necessário o armazenamento, sugere-se que sejam mantidos sob refrigeração a $4^{\circ} \mathrm{C}$, desde que sejam respeitadas as condições de embalagem, de preferência à vácuo.

PALAVRAS-CHAVE: Ipomoea batatas. Cultivos agrícolas. Controle de qualidade. Sensorial. Nutrição.

\section{REFERENCES}

ALESSANDRINI, L.; BALESTRA, F.; ROMANI, S.; ROCCULI, P.; ROSA, M. D. Physicochemical and sensory properties of fresh potato-based pasta (gnocchi). J. Food Sci., v. 75, p. 542-547, 2010. http://dx.doi.org/10.1111/j.1750-3841.2010.01842.x

ALLEN, J. C.; CORBITT, A. D.; MALONEY, K. P.; BUTT, M. S.; TRUONG, V. Glycemic Index of Sweet Potato as Affected by Cooking Methods. The Open Nutr. J., v. 6, p. 1-11, 2012.

http://dx.doi.org/10.2174/1874288201206010001

ASSOCIAÇÃO BRASILEIRA DAS INDÚSTRIAS DE MASSAS ALIMENTÍCIAS - ABIMA. Types of pasta: statistics. São Paulo, 2013. Available at: <http://www.abima.com.br/estatisca_massasphp\#tabs>. Accessed on: July 30, 2013.

ASSOCIATION OF OFFICIAL ANALYTICAL CHEMISTS (AOAC). Official methods of analysis of the Association Analytical Chemists. 18.ed. Gaithersburg, Maryland, 2005.

BOX, G. E. P.; DRAPER, N. R. Empirical model-building and response surface. New York: Wiley, 1987. $669 \mathrm{p}$.

CARINI, E.; VITTADINI, E.; CURTI, E.; ANTONIAZZI, F. Effects of different shaping modes on physicochemical properties and water status of fresh pasta. J. Food Eng., v. 93, p. 400-406, 2009. http://dx.doi.org/10.1016/j.jfoodeng.2009.02.002

CIACCO, C. F.; CHANG, Y. K. Como fazer massas. $1^{\text {a }}$ ed. Campinas: Ícone Editora/Editora da Unicamp, 1986.

CHANG, Y. C.; FLORES, H. E. M. Qualidade tecnológica de massas alimentícias frescas elaboradas de semolina de trigo durum (T. durum L.). Cienc. Tecnol. Aliment., v. 24, n. 4, p. 487-494, 2004.

CUELHAR, K. C. Elaboração e vida de prateleira de nhoque congelado enriquecido com espinafre e farinha de soja. 2004. 35 f. Monografia (Especialização em Tecnologia de Alimentos)- Curso de Graduação em Nutrição, Universidade Metodista de Piracicaba, Lins. 2004. 


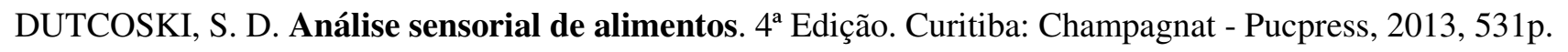

FAKHOURI, F. M.; TAKEITY, C. Y.; BERTAN, L. C.; REZENDE, D. F.; COLLARES, F. P. Aceitação e intenção de compra de massas alimentícias frescas enriquecidas com extratos vegetais. In: LATIN AMERICAN SYMPOSIUM ON FOOD SCIENCE - SLACA, 6., 2005, Campinas. Anais...Campinas, 2005. 1 CD-ROM.

HUMMEL, C. Macaroni Products. London: Food Trade Press, 1966, 287p.

LEITÃO, R. F. F.; GONÇAVES, J. R.; EIROA, M. N. U.; GARCIA, E. E. C. Tecnologia de macarrão. Campinas: ITAL, 1990.71p

LIMROONGREUNGRAT, K.; HUANG, Y.W. Pasta products made from sweet potato fortified with soy protein. Lebensm-wiss Technol., v. 40, p. 200-206, 2007. http://dx.doi.org/10.1016/j.lwt.2005.09.012

MELO, W. F.; GOMES L. M.; MOITA, A. W.; AMARO, G. B.; BESSA, F. P.; DUSI, A. N. Biofortificação no Brasil (BioFort): Avaliação preliminar de clones de batata-doce ricos em betacaroteno. In: CONGRESSO BRASILEIRO DE OLERICULTURA, 51., 2011, Viçosa. Anais...Viçosa: ABH.2675-2680. Available at:<http://www.academia.edu/3594992/Biofortifica\%C3\%A7\%C3\%A3o_no_Brasil_BioFort_Avalia\%C3\%A7 \%C3\%A3o_preliminar_de_clones_de_batata-doce_ricos_em_betacaroteno $>$. Acessed on: March 20, 2015.

PAUCAR-MENACHO, L. M.; SILVA, L. H.; BARRETO, P. A. A.; MAZAL, G.; FAKHOURI, F. M.; STEEL, C. J.; COLLARES-QUEIROZ, F. P. Development of functional fresh pasta with the addition of soy protein isolate and polydextrose using paprika coloring. Cienc. Tecnol. Aliment., v. 28, n. 4, p. 767-778, 2008.

TAVARES, L.L.; GUTIERREZ, E.M.R. Physico-chemical composition and sensorial characteristics of a gnocchi prepared with soy flour and oat bran, stored frozen. Nutrire, v.33, n. 3, p. 97-109, 2008.

RANGEL, C. N.; SILVA, E. M. M.; SALVADOR, L.; FIGUEIREDO, R.; WATANABE, E.; SILVA, J. B. C.; CARVALHO, J. L. V.; NUTTI, M. R. Sensory evaluation of cakes prepared with orange-fleshed sweet potato flour (Ipomoeas batatas L.). Perspect. Nutr. Hum., v. 13, p. 203-211, 2011.

SICILIANO, I.; SILVA, E. M. M.; SILVA, J. B. C.; WATANABE, E.; CARVALHO, J. L. V.; NUTTI, M. R. Avaliação da concentração de carotenóides em biscoitos formulados com farinha de batata-doce de polpa alaranjada. In: REUNIÃO ANUAL DE BIOFORTIFICAÇÃO NO BRASIL, 3., 2009, Aracaju.

Anais...Aracaju: Embrapa Tabuleiros Costeiros, 2009. 1 CD-ROM. (Embrapa Tabuleiros Costeiros.

Documentos, 148).

SOBOTA, A.; ZARZYCKI, P. Effect of pasta cooking time on the content and fractional composition of dietary fiber. J. Food Quality, v. 36, p. 127-132, 2013. http://dx.doi.org/10.1111/jfq.12023

ZEPPA, G.; ROLLE, L.; ALESSANDRIA, V. Gnocchi ed analisi di struttura (in Italian). Pasta\&Pastai, v. 43, p. 44-48, 2005. 